\title{
EVOLUTION OF DUFFING'S EQUATION SOLUTION OBTAINED WITH APPROXIMATED IMPULSE PROCESS EXCITATION
}

\author{
Ewa Ladyga ${ }^{1}$, Wladystaw Pękala ${ }^{2}$ \\ ${ }^{I}$ Institute of Mathematics, Częstochowa University of Technology \\ Częstochowa, Poland \\ ${ }^{2}$ Institute of Econometrics and Computer Science, Częstochowa University of Technology \\ Częstochowa, Poland \\ ewa.ladyga@gmail.com,wlad.pekala@gmail.com
}

\begin{abstract}
This paper describes the use of one of the methods to generate the impulse periodic process, called the rectangularization method, based on the Mikusiński-Sikorski distribution approach, to investigate the influence of impulse excitation approximation accuracy on chaotic properties of solutions of the Duffing's equation. The evolution of these solutions has been illustrated with Poincaré map graphs.
\end{abstract}

\section{Introduction}

The use of impulse waveform in numerical modeling of dynamic systems is associated with numerous technical difficulties. There are many known and usable ways to generate such wave forms (e.g. [1]), but using them in a specific numerical simulation usually causes destabilization of the computation processor a significant decrease in its efficiency, which is associated with the local fast function variability.

This paper describes the use of one of the methods to generate impulse periodic process, called the rectangularization method, based on the Mikusiński-Sikorski distribution approach [2], to investigate the influence of impulse excitation approximation accuracy on chaotic properties of solutions of Duffing's equation.

\section{Impulse process generating}

The following function sequence has been used to generate approximations of the impulse exciting process:

$$
p_{n}(t)=A \cdot \operatorname{sgn}(\cos \omega t) \cdot|\cos \omega t|^{\theta_{n}}
$$

where $\omega$ and $A$ are positive real numbers. $\theta_{n}$ denotes the monotonically decreasing convergent real numbers sequence where 


$$
0 \leq \theta_{n} \leq 1
$$

and

$$
\lim _{n \rightarrow \infty} \theta_{n}=0
$$

The evolution of the waveform graph shape depending on $\theta_{n}$ values has been shown in Figure 1. Smaller values of $\theta_{n}$ correspond to more rectangular shape of the function graph.

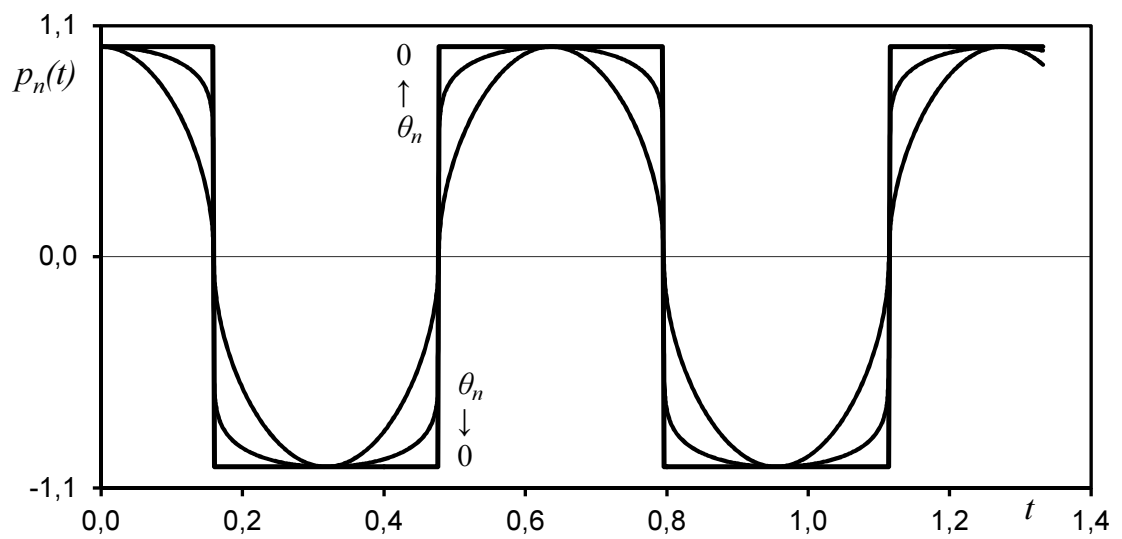

Fig. 1. The evolution of the waveform graph shape

\section{Dynamical system with impulse excitation}

A simple nonlinear dynamical system has been taken into account to observe dependence of chaotic properties of solution trajectory on approximation exactness of impulse excitation expressed by $\theta_{n}$ values. Equation of the system (Duffing's equation) has the form [3-5]:

$$
y^{\prime \prime}+\eta y^{\prime}+c y+\xi y^{3}=p_{n}(t)
$$

where $y=y(t)$.

Chaotic properties of this system were investigated and have been elaborated in detail in [3].

Initial conditions and equation parameters have been fixed at the following values:

$$
\begin{aligned}
& y(0)=0 \quad y^{\prime}(0)=0 \\
& \eta=0,1 \quad c=0 \quad \xi=1
\end{aligned}
$$




\section{Computation procedure}

The calculations were performed using the Runge-Kutta-Fehlberg procedure of numerical integration of ordinary differential equations. Excitation parameters values $\theta_{n}$ i $A$ have been changed according to variants described in Table 1 and Table 2. Different variants of the calculations have been marked by letters and digital symbols simultaneously (see: Tables 1 and 2).

Table 1

\begin{tabular}{|c|c|c|c|c|c|c|c|}
\hline Variant & $\mathrm{A}$ & $\mathrm{B}$ & $\mathrm{C}$ & $\mathrm{D}$ & $\mathrm{E}$ & $\mathrm{F}$ & $\mathrm{G}$ \\
\hline$\vartheta_{n}=$ & 1 & 0,9 & 0,8 & 0,7 & 0,65 & 0,6 & 0,58 \\
\hline
\end{tabular}

Table 2

\begin{tabular}{|c|c|c|c|c|c|c|c|c|c|c|}
\hline Variant & 01 & 02 & 03 & 04 & 05 & 06 & 07 & 08 & 09 & 10 \\
\hline$A=$ & 9,94 & 10,0 & 10,1 & 10,2 & 10,3 & 10,4 & 10,5 & 10,6 & 10,7 & 10,8 \\
\hline
\end{tabular}

\begin{tabular}{|c|c|c|c|c|c|c|c|c|c|}
\hline Variant & 11 & 12 & 13 & 14 & 15 & 16 & 17 & 18 & 19 \\
\hline$A=$ & 10,9 & 11,0 & 11,1 & 11,2 & 11,3 & 11,4 & 11,5 & 11,6 & 11,64 \\
\hline
\end{tabular}

The phase trajectories obtained by solving the equation (4) have been transformed with Poincaré mapping [4], so each calculation variant has been finished with a point characteristic of the solution (Poincaré map) which is an attractor of system (4) in phase space.

\section{Results}

Poincaré map graphs obtained as a result of computation have been presented in pictures of Figure 2. Each graph has been drawn in the same scale of state coordinates $\left(y, y^{\prime}\right)$ :

$$
\left(y, y^{\prime}\right) \in\langle 1,5\rangle \times\langle-10,10\rangle
$$

and has been denoted with a corresponding variant mark.

There are no Poincaré map graphs for variants A nor B in the Figure 2 because all of these solutions are chaotic and have similar characteristics. Also, the graphs of variants 05-07 are similar to 04 and 08, variants 10-12 - to 09 and 13, variants 15-18 - to 14 and 19, therefore they have been omitted in the paper.

The Poincaré map graphs shown in Figure 2 determine the boundary line in the parameter space $\left[A, \theta_{n}\right]$ between chaotic solutions area and the periodic one. The marks identified the computation variants vs. parameters values has been collected in Table 3. Cells containing the variant marks indicate chaotic solution, cells with „o" letter indicate periodic solution. 


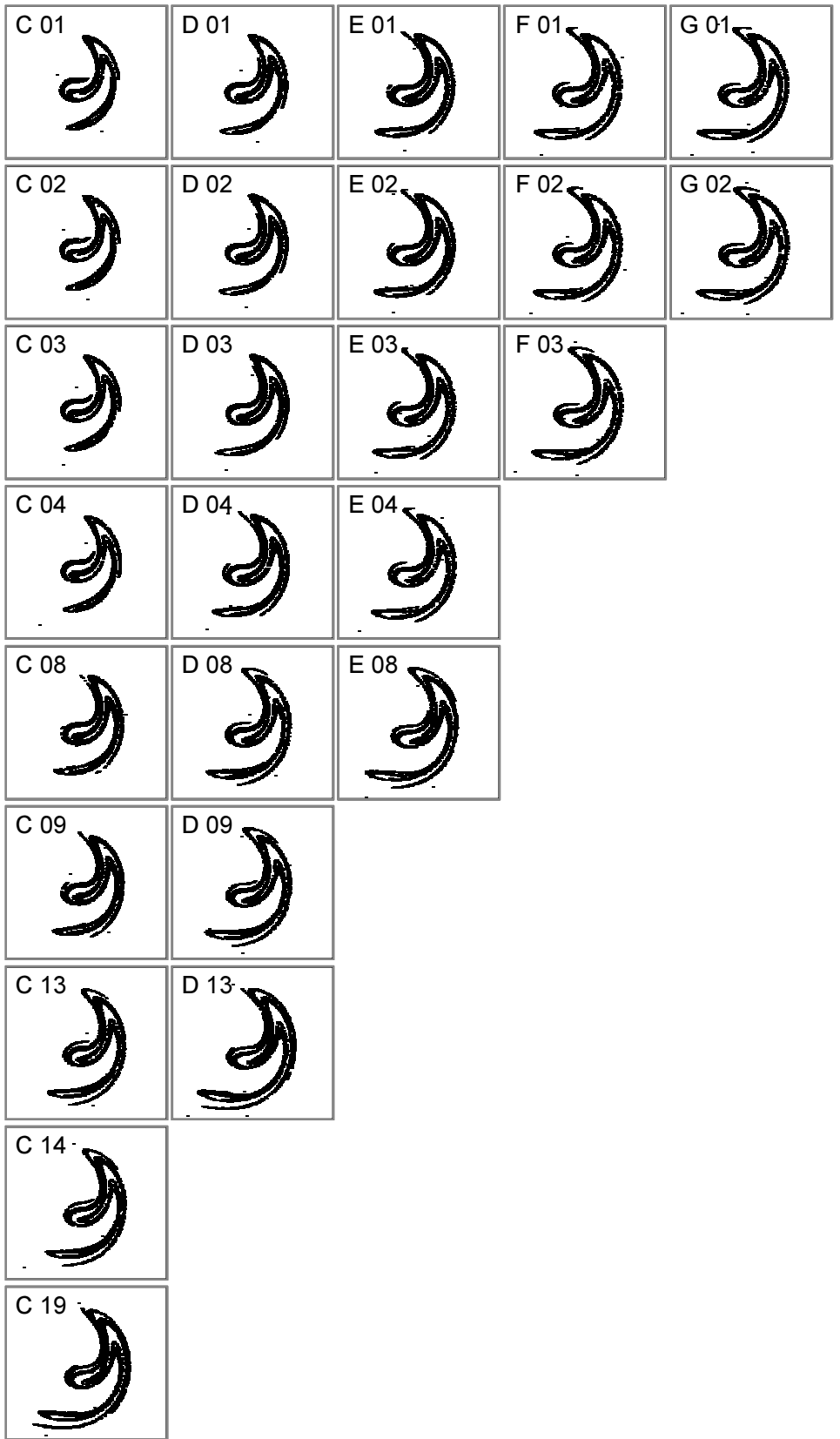

Fig. 2. The Poincaré maps

The lines bounding chaotic and periodic solution areasin the parameter space $\left[A, \theta_{n}\right]$ have been shown explicitely in Figure 3 . The space between lines (1) and (2) denotes solutions which should be investigated using a smaller sampling step of parameters values. 
Table 3

\begin{tabular}{|r|c|c|c|c|c|c|}
\hline \multirow{2}{*}{$\mathrm{A}$} & \multicolumn{6}{|c|}{$\vartheta_{n}$} \\
\cline { 2 - 8 } & 0,80 & 0,70 & 0,65 & 0,60 & 0,58 & 0,57 \\
\hline 9,94 & C 01 & D 01 & E 01 & F 01 & G 01 & o \\
\hline 10,00 & C 02 & D 02 & E 02 & F 02 & G 02 & o \\
\hline 10,10 & C 03 & D 03 & E 03 & F 03 & o & o \\
\hline 10,20 & C 04 & D 04 & E 04 & o & o & o \\
\hline 10,60 & C 08 & D 08 & E 08 & o & o & o \\
\hline 10,70 & C 09 & D 09 & o & o & o & o \\
\hline 11,10 & C 13 & D 13 & o & o & o & o \\
\hline 11,20 & C 14 & o & o & o & o & o \\
\hline 11,64 & C 19 & o & o & o & o & o \\
\hline
\end{tabular}

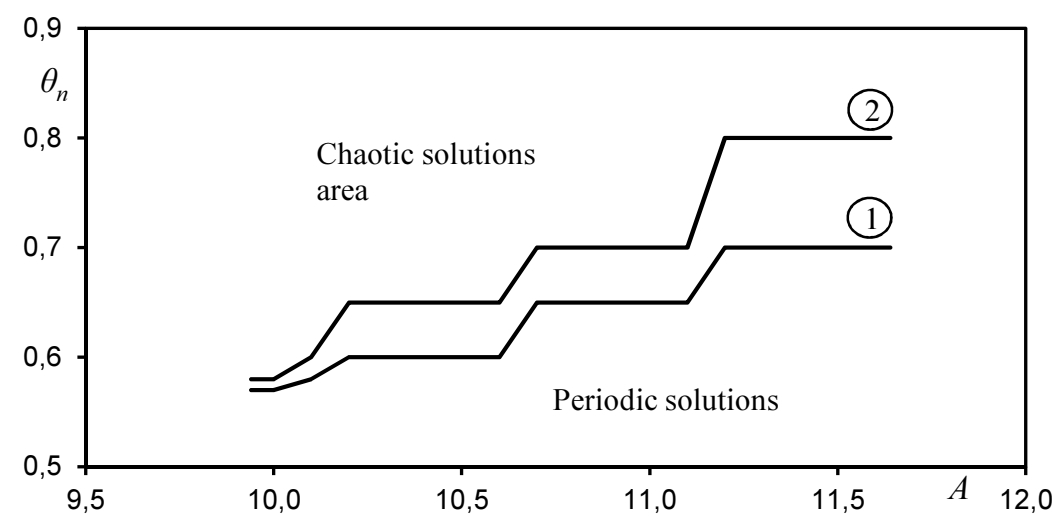

Fig. 3. The chaotic-periodic areas boundary lines

\section{Conclusions}

Computations described in this paper show the essential influence of the impulse waveform approximation accuracy on the dynamic system behavior. In particular, decreasing of parameter $\theta_{n}$ value ie. increasing of impulse waveform approximation accuracy reduces the chaotic properties of system (4) solutions they are going to be periodic ones. It depends strongly on excitation amplitude magnitude $A$.

\section{References}

[1] Polanowski S., Wygładzanie wykresów indykatorowych ruchomymi obiektami aproksymującymi z więzami łamanymi, Zeszyty Naukowe Akademii Marynarki Wojennej 2006, 1(164)/ (in Polish). 
[2] Ladyga E., Pękała W., Resonance properties of dynamical system with rectangularized excitation, Fourth International Conference on Parallel Processing and Applied Mathematics, PPAM 2001.

[3] Ueda Y., Steady Motions Exhibited by Duffing's Equation: A Picture Book of Regular and Chaotic Motions. In: New Approaches to Nonlinear Problems in Dynamics, Philadelphia, SIAM 1980.

[4] Awrejcewicz J., Mosdorf R., Analiza numeryczna wybranych zagadnień dynamiki chaotycznej, WNT, Warszawa 2003 (in Polish).

[5] Łuczko J., Drgania regularne i chaotyczne w nieliniowych układach mechanicznych, Wydawnictwo Politechniki Krakowskiej, Kraków 2008 (in Polish). 